\title{
Experiences with Wastes and Composts in Nursery Substrates
}

\author{
Calvin Chong
}

ADDITIONAL INDEX WORDs. media, container production, waste recycling, organic by-products, ornamentals

Summary. During the past 20 years, the Ornamental Nursery Research Program at the former Horticultural Research Institute of Ontario (now part of the University of Guelph) has been conducting applied research dealing with environmentally friendly and sustainable nursery production practices with emphasis on container production. The use of farm, industrial, and consumer waste byproducts as amendments in nursery substrates has been a major focus. The program has evaluated hundreds of potting mixes derived from individual or combined, raw or composted waste by-products including spent mushroom compost, turkey litter compost, paper mill sludge, municipal waste compost, corrugated cardboard, apple pomace, wood chips from pallets, pulverized glass, and various types of tree barks. With few exceptions, all the above waste byproducts tested under our cultural conditions provided acceptable to excellent container-growing media, often in amounts exceeding $50 \%$ and sometimes up to $100 \%$ by volume in No. 2 containers $(6$ $\mathrm{L})$, even despite initially elevated and potentially toxic contents of soluble salts [expressed in terms of electrical conductivity measured up to $8.9 \mathrm{dS} \cdot \mathrm{m}^{-1}$ in 1 substrate $: 2$ water (by volume) extracts] in many of the substrates. A key to these successful results is that salts leach quickly from the containers to benign levels $\left(\sim 1.0 \mathrm{dS} \cdot \mathrm{m}^{-1}\right)$ with normal irrigation practices. High initial $\mathrm{pH}$ in most waste-derived substrates (up to 8.9) has had little or no discernible effect on growth of a wide assortment of deciduous nursery species. By-products such as paper mill sludge and municipal waste compost with soluble salts contents typically ranging from 0.8 to $2.0 \mathrm{dS} \cdot \mathrm{m}^{-1}$, also provide acceptable rooting media provided salts are leached before use to values $\leq 0.2 \mathrm{dS} \cdot \mathrm{m}^{-1}$. The porosity and aeration characteristics of waste-derived substrates tend to be comparable to, or better than, those of bark.

\begin{tabular}{llll}
\hline $\begin{array}{l}\text { Units } \\
\text { To convert U.S. to SI, } \\
\text { multiply by }\end{array}$ & U.S. unit & SI unit & $\begin{array}{l}\text { To convert SI to U.S., } \\
\text { multiply by }\end{array}$ \\
\hline 0.4047 & $\mathrm{acre}(\mathrm{s})$ & $\mathrm{ha}$ & $2.471 \mathrm{l}$ \\
3.7854 & $\mathrm{gal}$ & $\mathrm{L}$ & 0.2642 \\
1 & $\mathrm{mmho} / \mathrm{cm}$ & $\mathrm{dS} \cdot \mathrm{m}^{-1}$ & 1 \\
28.3495 & $\mathrm{oz}$ & $\mathrm{g}$ & 0.0353 \\
1 & $\mathrm{ppm}$ & $\mathrm{mg} \cdot \mathrm{kg}^{-1}$ & 1 \\
0.9072 & ton $(\mathrm{s})$ & $\mathrm{t}$ & 1.1023
\end{tabular}


C ontainer production has increased rapidly and represents $35 \%$ to $40 \%$ of Canadian-grown nursery stock. It is intensive, specialized agriculture, requiring large amounts of potting amendments, particularly bark and peat moss, a non-readily renewable resource. Since 1984, the Ornamental Nursery Research Program at the former Horticultural Research Institute of Ontario-now part of the Department of Plant Agriculture, University of Guelph-has been conducting applied research dealing with environmentally friendly, alternative production practices with emphasis on container production (Chong, 1999a, 2001; Chong and Hamersma, 1995a).

With the increasing interest in waste recycling, researchers worldwide have been advocating the recycling and use of organic wastes and composts as soil or potting amendments, or as substitutes for animal manures, bark, and peat moss (Hoitink, 2000; Logan et al., 1997; Oshins, 1995; Shiralipour et al., 1994; Warman and Taylor, 2000). These uses offer alternative ways for society to dispose of garbage and waste and to conserve landfill space. Major deterrents for use include: obnoxious odors; variability in quality from year to year; possible presence of contaminants such as heavy metals, organic chemicals, and plastic and glass residues; potential phytotoxicity due to individual nutrients and/or high salt levels; unsatisfactory $\mathrm{pH}$, which may cause micronutrient deficiencies; and differences in species response. Except perhaps for bark, one of the most desirable and often-used substrate components (Davidson et al., 2000 ), the use of waste by-products in nursery substrates is not well defined or scientifically documented.

This report compares the characteristics of selected wastes and composts, and highlights our experiences of their use in nursery substrates during the past 20 years.

\section{Spent mushroom compost}

Spent mushroom compost is the organic substrate ( $45 \%$ dry matter) that is discarded after mushroom production is completed. In Ontario, the substrate is made from a blend of products that can include wheat straw-bedded horse manure, poultry litter, brewer's grain, soya bean meal, gypsum, urea, or ammonium nitrate (Chong et al., 1991a). The spent material (Table 1 ) is rich in certain nutrients and has physical properties, such as aeration porosity and water retention capacity, comparable to or better than those of bark (Table 1 ).

It is perhaps noteworthy that for over 50 years, spent compost has been used as a primary feedstock by the 100-acre Waterdown Garden Supplies Ltd. (Troy, Ont.), Canada's largest composter and soil blending-bagging operation (Chong and Hamersma, 1997). Up until the mid 1980s, spent mushroom compost in Ontario was considered primarily as a by-product of little or no value. It was commonly set aside to weather or distributed free or at a nominal cost. Due to increasing demand for spent mushroom compost by soil blending and composting operations and for its use in landscaping and reclamation projects, the weathered material is scarce or no longer available. During the 1980s, several Ontario nurseries were successfully growing shrubs in container mixes containing up to $50 \%$ by volume of spent compost (Chong and Wickware, 1989; Chong et al., 1990a).

Researchers have reported the use of spent mushroom compost as a soil or potting mix supplement to grow crops including fruit (Kaddous and Morgans, 1986), vegetables (Wang et al., 1984), corn (Zea mays) (Wuest et al., 1995a), and potted foliage (Henny, 1979) and

Table 1. Comparative chemical and physical analysis of traditional rooting medium materials and of selected waste by-products and composts. ${ }^{z}$

\begin{tabular}{|c|c|c|c|c|c|c|c|c|c|c|c|c|c|c|}
\hline \multirow{2}{*}{ Variable } & \multirow[b]{2}{*}{$\begin{array}{l}\text { Desirable } \\
\text { values for } \\
\text { container } \\
\text { culture }\end{array}$} & \multicolumn{3}{|c|}{ Traditional materials } & \multicolumn{6}{|c|}{ Individual waste by products } & \multicolumn{4}{|c|}{ Composts } \\
\hline & & Sand & Perlite & Peat & Bark & $\begin{array}{l}\text { Wood } \\
\text { chips }\end{array}$ & $\begin{array}{c}\text { Hemp } \\
\text { chips }\end{array}$ & Coir & Sawdust & $\begin{array}{c}\text { Paper } \\
\text { mill } \\
\text { sludge }\end{array}$ & $\begin{array}{c}\text { Leaf and } \\
\text { yard waste } \\
\text { compost }\end{array}$ & $\begin{array}{c}\text { Houschold } \\
\text { waste } \\
\text { compost }\end{array}$ & $\begin{array}{c}\text { Spent } \\
\text { mushroom } \\
\text { compost }\end{array}$ & $\begin{array}{c}\text { Turkey } \\
\text { litter } \\
\text { compost }\end{array}$ \\
\hline $\mathrm{pH}^{\prime}$ & $5.5-7.0$ & 7.8 & 7.6 & 4.0 & 6.3 & 7.9 & 7.3 & 5.4 & 5.8 & 7.2 & 8.4 & 8.4 & 8.2 & 8.7 \\
\hline \multirow[t]{2}{*}{ Eloctrical conductivity $\left(\mathrm{dS} \cdot \mathrm{m}^{-1}\right)^{y}$} & $\leq 10$ & 0.1 & $<0.1$ & 0.1 & 0.1 & 0.3 & 0.4 & 1.0 & 0.1 & 1.2 & 1.7 & 3.0 & 4.0 & 4.1 \\
\hline & \multicolumn{14}{|c|}{ Nutrients } \\
\hline Ammonium-nitrogen (ppen) $)^{5}$ & $\leq 1$ & 0.5 & 0.02 & 2 & 0.02 & 0.2 & 2 & 0.3 & 0.5 & 37 & . & 4 & 15 & 103 \\
\hline Nitrate-nitrogen (ppm) & $100-200$ & 5 & 0.02 & 3 & 0.02 & 0.2 & 50 & 0.1 & 0.01 & 0.02 & 3 & 0.02 & 89 & 232 \\
\hline Phosphorus (ppen) & $6-9$ & 0.05 & 0.05 & 0.3 & 8 & 0.1 & 11 & 3 & 0.5 & 8 & 1 & 2 & 6 & 27 \\
\hline Potassium (ppen) & $150-200$ & 6 & 0.8 & 0.6 & 42 & 25 & 420 & 173 & 54 & 89 & 733 & 1166 & 2066 & 2792 \\
\hline Calciium (ppm) & $200-300$ & 30 & 1.3 & 3 & 34 & 40 & 33 & 5 & 9 & 409 & 114 & 165 & 871 & 100 \\
\hline Magnesium (ppm) & $70-200$ & 16 & 0.6 & 1 & 12 & 6 & 13 & 3 & 1 & 83 & 48 & 50 & 220 & 153 \\
\hline Sodium (ppm) & $0-50$ & 10 & 6 & 5 & 10 & 20 & 2 & 75 & 6 & 387 & 89 & 139 & 511 & 501 \\
\hline Chloride (ppm) & $0-50$ & 14 & 6 & 7 & 19 & 8 & - & 203 & 25 & 136 & 986 & 848 & 1328 & 1656 \\
\hline Sulfate (ppm) & $0-80$ & 10 & - & - & 3 & - & - & - & - & 159 & - & 29 & 894 & 316 \\
\hline Iron (ppm) & $0.3-3.0$ & 0.5 & 0.2 & 0.2 & 0.5 & 0.4 & 1.2 & 0.4 & 0.4 & 1.4 & 0.2 & 1.5 & 1.9 & 11.4 \\
\hline Manganese (ppen) & $0.3-3.0$ & 0.05 & 0.1 & 0.1 & 0.6 & 0.2 & 0.3 & 0.1 & 0.3 & 1.4 & $\mathbf{0}$ & 0.1 & 0.9 & 2 \\
\hline \multirow[t]{2}{*}{ Zine (ppm) } & $0.3-3.0$ & 0.05 & 0.1 & 0.1 & 0.05 & 0.2 & 0.3 & 0.1 & 0.2 & 0.5 & 0.1 & 0.1 & 0.4 & 6.3 \\
\hline & \multicolumn{14}{|c|}{ Physical properties } \\
\hline Bulk density $\left(\mathrm{g}^{\mathrm{cm}} \mathrm{em}^{-3}\right)$ & $0.2-0.75$ & 1.50 & 0.12 & 0.11 & 0.20 & 0.15 & - & 0.1 & 0.23 & 0.43 & 0.57 & 0.55 & 0.39 & 0.31 \\
\hline Aeration porosity (\%) & $15-30$ & 14 & 32 & 30 & 46 & 41 & - & 29 & 18 & 40 & - & 32 & 40 & 45 \\
\hline Water retention capacity $(\%)$ & $25-35$ & 13 & 24 & 58 & 32 & 26 & - & 56 & 53 & 31 & - & 34 & 31 & 28 \\
\hline
\end{tabular}

${ }^{\text {2} S o u r c e: ~ C h o n g, ~ 2002 a . ~}$

${ }^{\mathrm{y}} \mathrm{pH}$ and electrical conductivity (a measure of soluble salts concentration) measured in 1 substrate: 2 water (by volume) extracts.

${ }^{x}$ Concentrations of all nutrients measured in saturated medium extraction (greenhouse) procedure $\left(1 \mathrm{ppm}=1 \mathrm{mg} \cdot \mathrm{kg}^{-1}\right)$. 
greenhouse flowers (Dallon, 1987; Maher, 1991). Because of the elevated salt content in spent compost and hence, its high potential for "burning" plants, researchers expressed concern or recommended against using it in plant culture (Eames, 1977; Lemaire et al., 1985; Smith, 1982). Chong and Rinker (1994) reviewed use of spent compost for growing container nursery crops and Wuest et al. (1995b) published proceedings from a symposium dealing with spent mushroom compost use in agriculture.

Among various laboratory-based chemical and physical parameters that characterize substrate and waste materials (Table 1 ), electrical conductivity [EC (a measure of soluble salts concentration)] and $\mathrm{pH}$ are perhaps the two that are likely considered first since these provide a "quick" indication of desirability and quality. An early survey of freshly discarded spent mushroom compost from five farms across Ontario indicated that the soluble salts concentrations ranged between 4.9 and 8.3 $\mathrm{dS} \cdot \mathrm{m}^{-1}$, as determined in 1 compost $: 2$

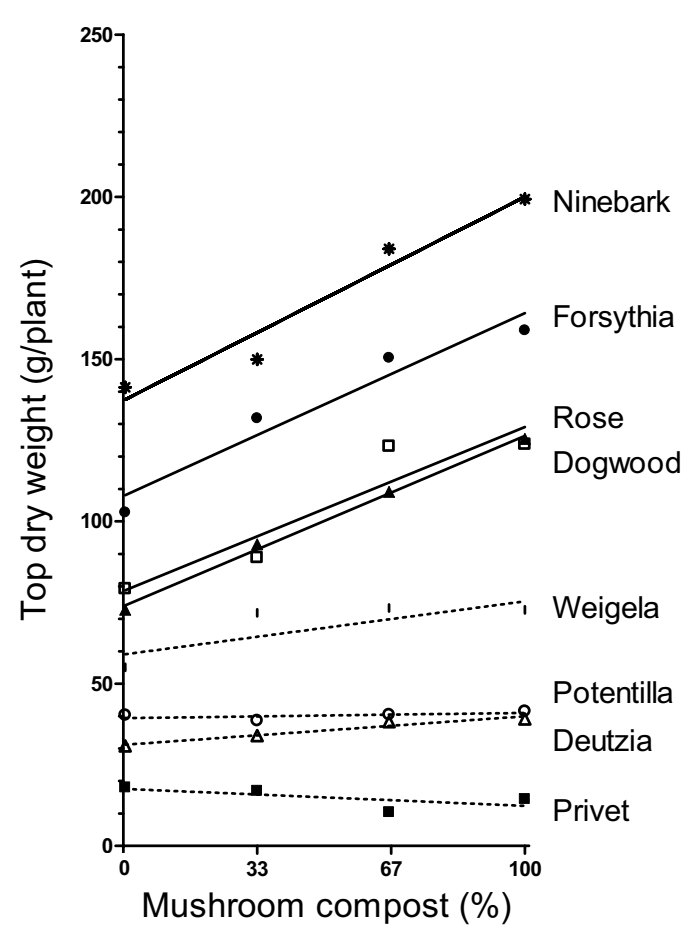

Fig. 1. Effect of increasing percentages of spent mushroom compost mixed with bark on top dry weight response $(1 \mathrm{~g}=\mathbf{0 . 0 3 5 3 \mathrm { oz }})$ of eight container-grown deciduous ornamental shrubs: ninebark (Physocarpus opulifolius), forsythia (Forsythia $\times$ intermedia 'Lynwood'), rose (Rosa 'John Franklin'), dogwood (Cornus alba 'Argenteo-marginata'), weigela (Weigela florida 'Variegata Nana'), potentilla (Potentilla fructiosa' Red Ace'), deutzia (Deutzia gracilis), and privet (Ligustrum vulgare) (Chong and Rinker, 1991). water extracts (byvolume) (Chong and Rinker, 1994; Chong et al., 1991b, 1991c). These values far exceeded our recommended threshold value of $\mathrm{dS} \cdot \mathrm{m}^{-1}$ for initial salt content in ursery container substrates or amendelevated salt levels were due primarily to excessive amounts of potassium $(\mathrm{K})$, cium $(\mathrm{Ca})$, chloride $(\mathrm{Cl})$, sodium a), and sulphate $\left(\mathrm{SO}_{4}\right)$. The $\mathrm{pH}$ of the composts ranged from 7.6 to 8.2. These values were above the 5.5 to .0 desirable range recommended for eneral nursery plant culture [Ontario Ministry of Agriculture and Food (OMAF), 2003].

Notwithstanding these results, in our early container trials in the mid1980s, which included spent compost in incremental amounts up to $100 \%$, encompassing all possible volume blending ratios, we obtained good to cellent growth of a wide assortment y deciduous nursery species in No. 2 containers (Chong and Rinker, 1994). There was little difference when freshly spent (high salt level), leached (low salt level), or aged (intermediate salt level) composts were used. Most species grew more as the proportion of compost mixed with bark was increased, in some cases, up to the maximum amount of compost (Fig. 1).

The key to our successful results was that the salts leached quickly from the containers with normal irrigation practices (Chongetal., 199lb, 1991d), declining to values that were benign within days after potting (Fig. 2). Later studies (Chong, 2004; Chong and Purvis, 2004) and those of other researchers (Young et al., 2002) reconfirmed these results.

Growers in both Canada and the U.S. often reported successful use of spent compost. A few have reported phytotoxicity due primarily to high salts and, to a lesser extent, high $\mathrm{pH}$, especially when rhododendrons (Rhododendron spp.), azaleas (Azalea spp.), and other acid-requiring plants are grown. These plants are sensitive both to high salts and high $\mathrm{pH}$. Species vary in degree of tolerance to both salt (Skimina, 1980) and pH (Maynard, 2002). In our spent compost studies with a wide assortment of deciduous species, we have rarely observed symptoms that would be attributed to high salts and/or $\mathrm{pH}$.

While we demonstrated that it is possible to use relatively large amounts of spent mushroom compost in the container substrates, amounts used in actual growing conditions rarely, if ever, exceed $50 \%$. More often, amounts are in the range of $10 \%$ to $20 \%$. With these lower amounts, there is much less likelihood of a problem due to high salts or $\mathrm{pH}$. Amounts of spent compost greater than $50 \%$ of the mix may result in excessive substrate subsidence (Chong et al., 1994) or reduced water-holding capacity (Young et al., 2002).

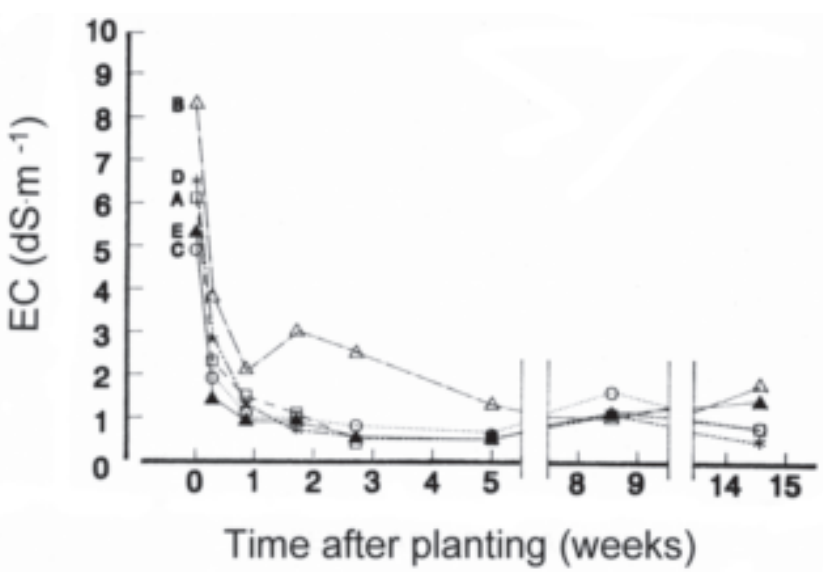

Fig. 2. Changes in electrical conductivity [EC (a measure of soluble salts concentration)] of five sources of freshly-discarded spent mushroom compost in No. 2 [6 L (1.6 gal)] containers subjected to normal irrigation practices during the growing season (Chong and Rinker, 1994). 
Until experience is gained, we recommend that the salt level in the spent compost mix be monitored, particularly during the first several days after potting when hazard level is the highest. The mix should never be allowed to dry out since this increases the potential for salt burning. Use spent compost only in smaller containers since salts leach slowly from large containers. In pot-in-pot culture, we have observed decreased growth, or tree loss, due to prolonged high salt retention in large (10 and 25 gal) containers (Chong and Lumis, 2000).

\section{Turkey litter compost}

During the past decade, Nors Hydro (formerly Hydro Agri Canada L.P.), Elmira, Ont, has been marketing locally produced turkey litter compost primarily for use on golf courses. Sustane, a granulated organic amendment/fertilizer product derived from turkey litter compost, available in the U.S. and Canada, has also been evaluated as a soil amendment for ginseng production in Ontario (Reeleder and Capell, 2001). This product has been shown to have disease-suppressing properties on turf and has largely been sold for use on golf courses. Tyler et al. (1993) and Kraus and Warren (2000) grew container crops in turkey litter compost. Ku et al. (1998) grew potted poinsettia (Euphorbia pulcherrima) in poultry litter compost-amended substrates.

Turkey litter compost (Table 1) has chemical composition and physical properties, including salt levels and $\mathrm{pH}$, that are somewhat similar to those of spent mushroom compost, and should be handled similarly. However, unless the turkey litter compost is properly aged [i.e., an ammonium-nitrogen $\left(\mathrm{NH}_{4}-\mathrm{N}\right)$ content of $\left.\leq 10 \mathrm{ppm}\right]$, it may contain excessive amounts of $\mathrm{NH}_{4}-\mathrm{N}$, which by itself is potentially phytotoxic.

Our first trial with turkey litter compost (unamended: $\mathrm{EC}=\mathbf{5 . 9}$ $\mathrm{dS} \cdot \mathrm{m}^{-1}$, and $\mathrm{pH}=8.9$ ) demonstrated that, like spent mushroom compost, it was possible to use relatively large amounts ( $60 \%$ or more) mixed with bark to grow silverleaf dogwood (Cornus alba 'Argenteo-marginata'), common ninebark (Physocarpus opulifolius), and slender deutzia (Deutzia gracilis) (Chong, 2000a). Growth was best when fertilizer top-dress [ $34 \mathrm{~g}$ per No. 2 container of $16 \mathrm{~N}-4.4 \mathrm{P}-8.3 \mathrm{~K}$
(Nutricote 16-10-10 Tl40 with micronutrients; Chisso-Asahi Fertilizer Co., Tokyo)] was delayed 2 weeks after planting vs. at planting or 4 weeks later.

In a comparative study of turkey litter compost and spent mushroom compost, we combined each in amounts between $25 \%$ and $50 \%$ with bark, sand, and/or paper mill sludge. While there were some differences in growth response of 'Sibirica' dogwood (Cornus alba), 'Lynwood' forsythia (Forsythia xintermedia), and 'Variegata Nana' weigela (Weigela florida), there was no clear indication that the turkey litter compost was consistently better than spent mushroom compost as a potting amendment (Chong, 2002b).

\section{Paper mill waste}

Paper mill sludge, sometimes referred to as biosolids, is the solid residue (30\% to $40 \%$ total solids, dry weight basis) from the treatment of effluent wastes ( $3 \%$ to $5 \%$ total solids) from pulping, papermaking, and paper recycling operations (Bellamy et al., 1990). The high cellulosic content makes these materials a good source of inexpensive organic matter.

The $\mathrm{pH}$ of Ontario paper mill sludges typically ranges between 7.0 and 7.5. Depending on source or batches of the same source, the nutrient concentrations vary widely, especially those of $\mathrm{Ca}, \mathrm{Na}, \mathrm{Cl}$, and $\mathrm{SO}_{4}(\mathrm{Bel}-$ lamy et al., 1990, 1995). The soluble salts content is relatively low (usually between 0.2 and $1.5 \mathrm{dS} \cdot \mathrm{m}^{-1}$ ) compared to spent mushroom or turkey litter compost (Table 1 ). In fact, the mineral composition tends to be comparable to that of cattle manure (Bellamy et al., 1995).

It is a common misconception that paper mill sludge is laden with heavy metals and toxic organic chemicals such as dioxins and polychlorinated biphenyls (PCBs). Ontario paper mill sludges contain very low quantities of heavy metals and organic chemicals, and are typically low enough to meet thresholds set by the Ontario Ministry of the Environment (Bellamy et al., 1995). In recent years, the concentrations of copper have tended to slightly exceed the threshold level of $60 \mathrm{ppm}$.

In the U.S., research on use of paper mill sludge began in the 1950s in marginal land reclamation [National Council of the Paper Industry for Air and Stream Improvement (NCASI), 1959], forestry (Brockway and Urie, 1983; Thacker, 1986), and agriculture (Dolar et al., 1972; Hermann, 1982). In Canada, paper mills in the Niagara area of Ontario first began to distribute and incorporate this by-product in farm soils and rehabilitation sites (Pridham and Cline, 1988). Subsequently, other paper mills introduced this practice to other regions of Ontario and Canada. Clear Lake (1993) published a compendium of paper sludge utilization by researchers in Canada and the U.S. Bellamy and Chong (1993) and Bellamy et al. (1995) reviewed paper mill sludge utilization in Ontario, including use in nursery substrates.

Prior to its use in Ontario agriculture, paper sludge was landfilled until tipping fees of \$90-95 per tonne made this practice uneconomical, or landfilling became prohibitive. Alternative uses were considered, such as energy source in incinerators; animal feed supplement, because of its high cellulose content; manufacture of flower pots, skeet targets, and building blocks; and restoration of gravel pits, building, and industrial sites (Pridham and Cline, 1988).

RAW SLUDGE. Early trials demonstrated that raw or unprocessed paper mill sludge mixed with soil, bark, or other ingredients can be used effectively for container growing. Growth of deciduous shrubs in containers increased primarily in response to increasing amounts of nitrogen $(\mathrm{N})$ initially present in different sources of paper sludges $(0.25 \%$ to $3.5 \% \mathrm{~N})$ (Chong et al., 1988). As a rule, we recommend no more than one-third of the mix as sludge (Bellamy et al., 1995), although with some batches or sources, up to two-thirds of the mix can be sludge (Chong, 2003a). We also successfully used mixtures of paper mill sludge, wood chips, bark, and peat in substrates for pot-in-pot shade tree production (Chong and Lumis, 2000). In the Niagara area, where paper mill sludge is readily available at no cost, a few nurseries routinely use it in potting mixes in amounts up to $20 \%$.

Composted SLudge. Since the early 1990s, several enterprises in the U.S. and Canada have recycled paper mill sludge as a traditional windrowcomposted feedstock material mixed with other ingredients (Campbell et al., 1991). Tripepi et al. (1996) used both 
raw and composted paper mill sludges in substrates for container growing of nursery crops.

In a trial comparing raw paper mill sludge vs. immature Phase I (end of active turning) and mature Phase II (aged) sludge-derived composts $(40 \%$ paper mill sludge and 60\% sawdust fortified with a patented bio-starter derived from processed chicken manure and recycled compost; former Grow-Rich Inc., Niagara Falls, Ontario, Canada), we found that any amount of the compost was suitable for growth of three container-grown crops [tartarian dogwood (Cornus alba), 'Coral Beauty' cotoneaster (Cotoneaster dammeri), and 'Variegata Nana' weigela] (Chong and Cline, 1994). Growth was little affected by immature or aged sludge-derived compost, indicating that, for the production of these species, the additional effort and costs for aging the sludge compost are unnecessary.

Notwithstanding these successes, the use of paper mill sludge in Ontario agriculture has produced variable and sometimes detrimental results, due in part to insufficient agronomic and research knowledge. Different sources of sludge, or even batches of the same sludge, vary in chemical and physical characteristics. Agronomic responses are not always similar at different locations or in different years, or when another sludge other than the one tested is used.

Obnoxious odor continues to be the most important deterrent for use of raw paper mill sludge in nursery substrates. Environmental Systems, St. Catharines, Ont., has developed a simple and innovative way to stabilize the material and get rid of the odor: by letting it stand in outdoor windrows without addition of other feedstock, fertilizer or other amendments for about 6 months and subjected only to occasional turning. This "composted" or processed product is odorless, more desirable for trucking and handling, and in our container trials was at least as effective and generally better as a container amendment than the raw product (Chong and Purvis, 2004).

\section{Municipal waste composts}

In Canada, as in other countries throughout the world, composting is considered a key to the management and reduction of municipal wastes (Hoitink, 2000; Shiralipour et al.,
1992; Warman and Taylor, 2000). During the 1990s, various municipalities across Canada passed waste reduction legislation. Ontario, which currently produces one-third of an estimated total of 1.5 million $t$ of finished municipal compost in Canada, requires all municipalities over 50,000 in population to compost all garden and yard waste.

Research in the 1940s demonstrated that compost from municipal waste almost always increased yields of field crops (Garner, 1962). Researchers have confirmed these results over a wide range of growing conditions with a wide range of agricultural and horticultural crops (Maynard, 1995; Rosen et al., 1993; Shiralipour et al., $1992,1994)$, as well as nursery crops (Maynard, 1998; Shiralipour et al., 1994).

With container nursery crops, municipal waste composts have produced beneficial results at rates up to $100 \%$ by volume (Shiralipour et al., 1994). Our first trial with composted municipal residential wastes from a pilot project-a precursor to largescale composting in Metro Toronto landfills - provided similar results for container-grown crops (Chong et al., $1990 \mathrm{~b}, 1991 \mathrm{c})$. There were also small but significant increases in foliar $\mathrm{N}$ content as the amount of municipal compost increased between 0 and $67 \%$. Since then, we have routinely and successfully used yard waste compost in our experimental container mixes from Metro Toronto Solid Waste Division, Keele Valley Landfill, and more recently municipal waste compost from the cities of Guelph and Waterloo. As exemplified by data for ninebark in Fig. 3 , nursery plants typically grow well (i.e., to at least minimum acceptable size for market) in these waste-compost derived substrates mixed with various other ingredients.

Municipalities will continue to be the primary source of composts. Currently, however, the ability of most municipalities to market or utilize the material in an environmentally sustainable manner continue to fall short of expectations (Chong, 1995, 2003b). Excess salts, high $\mathrm{pH}$, presence of plastic and glass residues, and variability in quality continue to be major deterrents against use of municipal composts in nursery substrates (Chong, 2003b). Also, there is no assurance that a nursery can obtain a large supply of compost from the same municipal source year after year.

\section{Waxed cardboard and other wastes}

In the U.S. and Canada, packaging material, which includes waxed corrugated cardboard as a major component, accounts for over $20 \%$ of landfill wastes. Waxed cardboard is difficult to recycle in the paper manufacturing industry (Chong and Hamersma, 1995b). The wax interferes with the papermaking process.

Chemical analysis indicates that waxed corrugated cardboard is low or lacking in nutrients and, in this respect, desirable as an amendment for container substrate (Chong and Hamersma, 1995b). Our first study in the 1990s showed that certain substrates consisting of $25 \%$ or $50 \%$ by volume of uncomposted waxed corrugated cardboard mixed with spent mushroom compost and/or sawdust supported growth of container-grown nursery species equal to a bark control medium or a commercial nursery mix (Chong and Hamersma, 1993).

Limited investigations at two composting operations in Ontario demonstrated that waxed corrugated cardboard could be satisfactorily used as a primary compost feedstock. Subsequently, we formulated and characterized 12 different composts derived from corrugated waxed cardboard (Raymond et al., 1997) and demonstrated that two of three containergrown nursery crops grew better in them than in control nursery substrates (Raymond et al., 1998).

OTHer wastes. We have also investigated other types of waste by-products in nursery substrates, including apple pomace, a by-product of the juice industry (Chong, 1992); industrial waste by-products from the manufacturing of polyvinyl chloride resins and compounds (Chong, 1999b); various types of softwood barks (Chong and Hamersma, 1991; Rowat, 2000); pulverized broken glass, and various types of animal manures (unpublished).

\section{Rooting substrates}

Sand, perlite, and peat contain few nutrients or soluble salts (Table 1) and are commonly used in rooting substrates. In contrast, the high salt content in organic wastes and wastederived composts is perhaps the single 


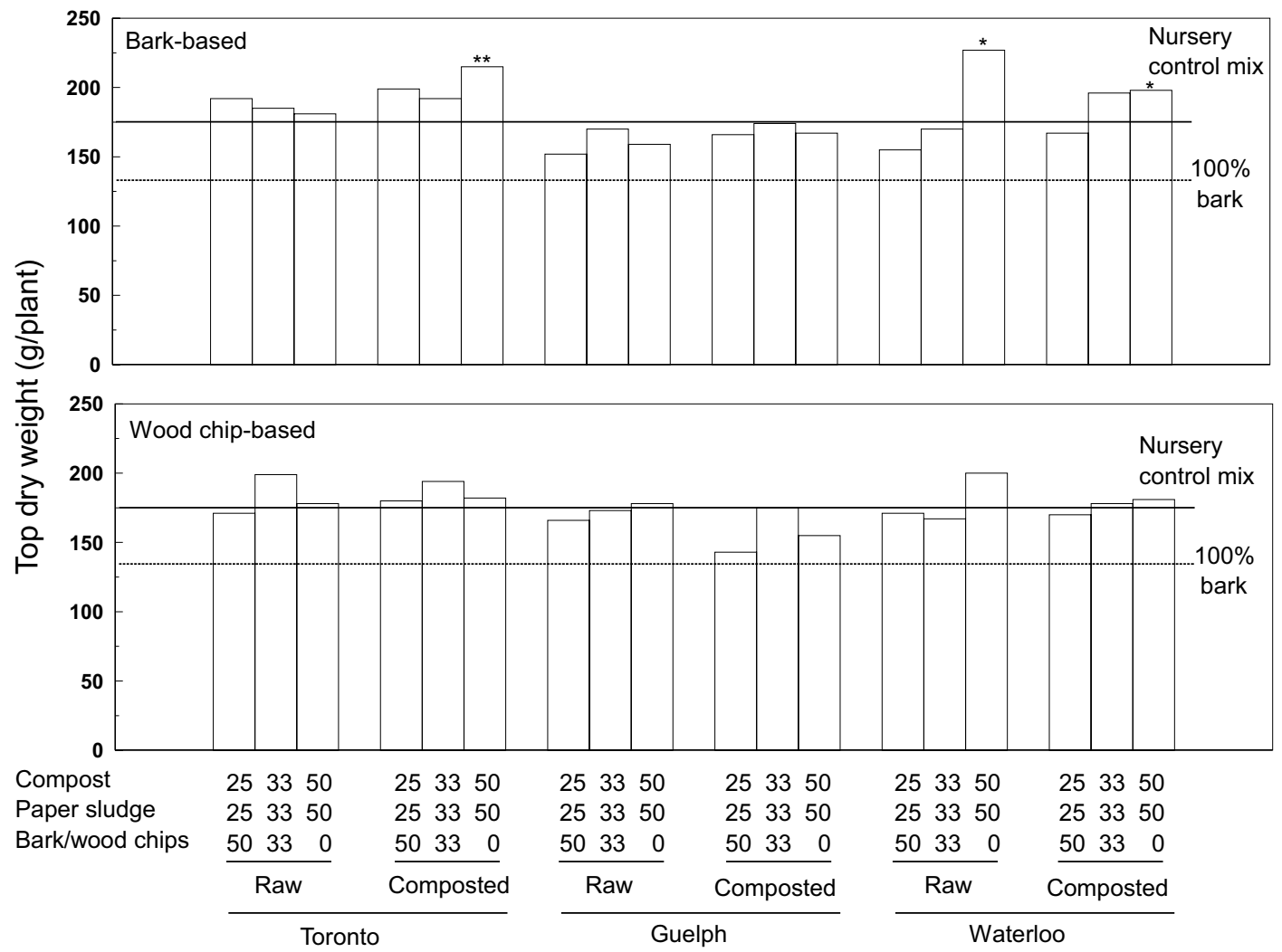

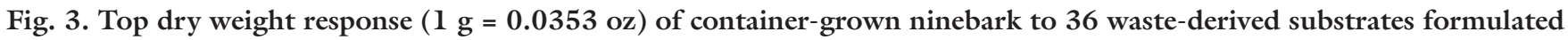
from: three sources of municipal waste compost (cities of Toronto, Guelph, and Waterloo) each at three rates (25\%, 33\%, or $50 \%$ by volume) mixed with raw or composted paper sludge $(25 \%, 33 \%$, or $50 \%)$, and the remainder consisting of one of two base supplements (bark or wood chips; $50 \%, 33 \%$, or $0 \%$ ) (Chong, 2003b). The lower horizontal dotted line represents top dry weight in $\mathbf{1 0 0 \%}$ bark where growth is considered to be the minimum acceptable size for market. The upper horizontal solid line represents top dry weight in a proven control nursery mix (80\% bark: $15 \%$ peat: $5 \%$ topsoil). Asterisks above bar indicate significantly more growth than with the nursery mix.

most important criterion that limits the potential for use of organic wastes and composts in propagation (Chong, 2002b; Skimina, 1980). Organic byproducts and composts, however, tend to have porosity and aeration characteristics comparable to, or better than, those of peat (Table 1) and, in this regard, are ideal substitutes in propagating media.

While high salt-containing materials such as spent mushroom compost and turkey litter compost are not recommended for rooting mixes (EC $>4.0$; Table 1), we have successfully used intermediate salt-containing paper mill sludge (EC $1.2 \mathrm{dS} \cdot \mathrm{m}^{-1}$ ) and municipal leaf and yard waste compost $\left(\mathrm{EC} 1.7 \mathrm{dS} \cdot \mathrm{m}^{-1}\right)$ in volume proportions up to $60 \%$ and $75 \%$, respectively, in rooting substrates (Chong, 1999c). For general use, however, we recommend lower proportions. When present in high proportions, sludges and composts, like peat, tend to make the substrates "too wet" due to their excessive water retention.
We routinely use a paper mill sludge and perlite (1:1 by volume) mixture for outdoor rooting under intermittent mist. However, we do not recommend its use for winter propagation in greenhouses with bottom heat. The sludge loses its friability and integrity under this condition. We also use mixtures of municipal leaf and yard waste compost and perlite ( $1: 1$ or $1: 3$, by volume). We prefer these sludge and compost mixtures because their initial contents of soluble salts are relatively low, the salts leach easily, and the waste products are readily and easily available in our area. We have obtained excellent rooting results using perlite mixed with coir, hemp chips, or wood chips, but not sawdust (unpublished data). These materials generally contain lower salt levels than paper mill sludge or waste composts (Table 1).

Salts leach quickly from propagating medium in shallow flats or plugs if levels are not too high $\left(<2.0 \mathrm{dS} \cdot \mathrm{m}^{-1}\right)$. Often, one or several irrigations, or just leaving the substrates in flats under mist for a day or two will result in leaching sufficient to lower salts to acceptable levels for rooting of cuttings $(\leq 0.2$ $\left.\mathrm{dS} \cdot \mathrm{m}^{-1}\right)$ (Chong etal., 1998). While this practice may render waste-derived substrates usable for propagation, it will require extra labor, time, and expense for leaching and for monitoring salt levels. For some propagators, this practice may be impractical, too much of a bother, or not worth the potential risk, and could be perceived as "unfriendly" if the leachates are simply allowed to flow into the ground-water environment. It is perhaps worth noting that, to complete the recycling loop, we have embarked on research whereby nutrient-laden leachates from compost operations, container nurseries, and compost teas, are reutilized as supplemental irrigation and/or fertilizer sources (Michitsch et al., 2003; Jarecki et al., 2005). Using waste materials in proportions less than $30 \%$ often by itself mitigates potential harm due to salts.

Since different sources of waste or compost, or even batches from the 
same source, may differ in chemical properties, we recommend that you determine the soluble salts concentration of the material and/or prepared medium before use. If the reading is higher than $0.2 \mathrm{dS} \cdot \mathrm{m}^{-1}$ (1 substrate : 2 water by volume extract), leach it and use only when the reading is below or very close to this value, or if you have prior knowledge that cuttings are tolerant of higher salt levels (Chong, $2000 \mathrm{~b}$ ). We have also observed that some composts and paper mill sludges leach easier than others.

\section{Conclusion}

Our nursery research has formulated and tested hundreds of substrates derived from raw or composted waste by-products. Our results and those of other scientists across the world confirm that these materials can be used effectively in nursery culture.

Since our studies were conducted in southern Ontario (lat. $43.2^{\circ} \mathrm{N}$, long. $-79.4^{\circ}$ ) where the environmental conditions are harsh in winter but mild in summer, and using primarily deciduous plant materials adapted to this climate, a substrate that performs well here may not do so in other regions with different climate, plant materials, and/or cultural conditions. In lower latitudes, for example, damage to plants may occur with high ammonia-containing substrates due to the high summer heat, or with high salt-containing substrates due to drought or moisture stress. A waste-derived substrate may start out with acceptable physical properties, but the length of time that a crop can be suitably grown in it may be limited due to changes such as composting in the container, shrinkage, and reduced air and water-holding characteristics. Substrate physical properties are described and discussed in an accompanying workshop paper by Bilderback et al. (2005).

While waste-derived materials are used only limitedly in current commercial practices, there may be immediate and obvious benefits for using them. This is true particularly if they are readily available or less expensive to use than traditional substrate materials.

In the long term, increased usage of waste-derived by-products and composts in response to environmental and societal pressures will position the nursery industry at the top of the environmentally friendly chart for being proactive in managing wastes.

\section{Literature cited}

Bellamy, K.L. and C. Chong. 1993. Plant responses in media amended with composts and organic wastes, p. 205-217. In: Proc. 3rd Annu. Mtg. Composting Council of Canada, Montreal, 23-24 Sept. 1993.

Bellamy, K.L., C. Chong, and R.A. Cline. 1995. Paper sludge utilization in agriculture and container nursery culture. J. Environ. Quality 24:1074-1082.

Bellamy, K.L., N. deLint, N.F. Pridham, and R.A. Cline. 1990. Agricultural utilization of paper mill sludge in the Niagara area, p. 65-81. In: Proc. 13th Intl. Symp. Wastewater Treatment and 2nd Wkshp. on Drinking Water, Montreal.

Bilderback, T.E., S.L. Warren, J.S. Owen, Jr., and J.P. Albano. 2005. Healthy substrates need physicals! HortTechnology 15:747-751

Brockway, D.G. and D.H. Urie. 1983. Determining sludge fertilization rates for forests from nitrate- $\mathrm{N}$ in leachate and ground-water. J. Environ. Quality 12:487-492.

Campbell, A.G., R.R. Engebretson, and R.R. Tripepi. 1991. Composting of combined RMP /CMP pulp and paper sludges. Tappi J. 74:183-191

Chong, C. 1992. Apple pomace as an amendment in container growing media. HortScience 27:138.

Chong, C. 1995. Compost! Compost! What to do with it. Landscape Trades $17(6): 29-31$.

Chong, C. 1999a. Experiences with the utilization of wastes in nursery potting mixes and as field soil amendments. Can. J. Plant Sci. 79:139-148.

Chong, C. 1999b. Two industrial waterderived wastes as potential potting amendments. Acta Hort. 481:165-172.

Chong, C. 1999c. Rooting of deciduous stem cuttings in peat- and perlite-amended MSW compost media. Compost Sci. Util. 7:6-14.

Chong, C. 2000a. Response of containerized nursery crops to level of turkey litter compost and time of fertilizer application, p. 917-933. In: P.R. Warman and B.R. Taylor (eds.). Proc. Intl. Compost Symp. (ICS 1999), Vol. II. CBA Press, Truro, N.S., Canada.

Chong, C. 2000b. Relationship of soluble salts content in MSW compost media and rooting of evergreen cuttings. Compost Sci. Utilization 8:29-35.

Chong, C. 2001. Turning wastes into resources. Landscape Trades 23(9):28-36.
Chong, C. 2002a. Using turkey litter compost in growing media. Comb. Proc. Intl. Plant Prop. Soc. 51:390-394.

Chong, C. 2002b. Use of waste and compost in propagation: Challenges and constraints. Comb. Proc. Intl. Plant Prop. Sci. 52:410-414.

Chong, C. 2003a. Paper mill waste mixed with compost and other ingredients as container nursery substrates. Compost Sci. Utilization 11:16-26.

Chong, C. 2003b. Compost markets: Capitalizing on current opportunities. Proc. Compost Council of Canada Compost Wkshp., 25 Mar. 2003. Compost Council of Canada, Toronto.

Chong, C. 2004. Comparative evaluation of spent mushroom compost, turkey litter compost and municipal waste compost in 18 waste-derived container nursery substrate. Acta Hort. 630:313-320.

Chong, C. and R.A. Cline. 1994. Response of container-grown nursery crops to raw and composted paper mill sludges. Compost Sci. Utilization 2:90-96.

Chong, C., R.A. Cline, and M. Koole. 1990a. Container media compared in trial at Brucedale. Landscape Trades 12(5):13-14, 16.

Chong, C., R.A. Cline, and D.L. Rinker. 1988. Use of paper mill sludge in container crop culture. Landscape Trades 10(7):17-18.

Chong, C., R.A. Cline, D.L. Rinker, and O.B. Allen. 1991a. Growth and nutrient status of containerized woody species in media amended with spent mushroom compost. J. Amer. Soc. Hort. Sci. 116:242-247.

Chong, C., R.A. Cline, and D.L. Rinker. 1991b. Rapid leaching of salts-Key to successful plant growth in spent mushroom compost potting mixes. Mushroom News 39(10):12-13.

Chong, C., R.A. Cline, and D.L. Rinker. 1991c. Organic wastes as growing media. Comb. Proc. Intl. Plant Prop. Soc. 41:399-403.

Chong, C., R.A. Cline, and D.L. Rinker. 1994. Bark- and peat-amended spent mushroom compost for containerized culture of shrubs. HortScience 29:781-784.

Chong, C. and B. Hamersma. 1991. Growth of containerized shrubs in pine bark of different ages. Hort. Rev. 9(6):12-15.

Chong, C. and B. Hamersma. 1993. Container nursery plant culture in waxed corrugated cardboard media. Comb. Proc. Intl. Plant Prop. Soc. 43:491-494. 
Chong, C. and B. Hamersma. 1995a. Environmentally friendly nursery production practices. Comb. Proc. Intl. Plant Prop. Soc. $45: 536-537$.

Chong, C. and B. Hamersma. 1995b. Growing plants with recycled cardboard. Biocycle 36(3):86-87.

Chong, C. and B. Hamersma. 1997. The adventures of Mr. Compost. Amer. Nurs. 185(5):26-31.

Chong, C., B. Hamersma, and K.L. Bellamy. 1998. Comparative rooting of deciduous landscape shrub cuttings in media amended with paper mill biosolids from four different sources. Can. J. Plant Sci. 78:519-526.

Chong, C., B. Hamersma, and R.A. Cline. 1990b. Recycled municipal waste shows promise in container plant production. Hort. Rev. 8(10):6-9.

Chong, C. and G.P. Lumis. 2000. Mixtures of paper mill sludge, wood chips, bark, and peat in substrates for pot-in-pot shade tree production. Can. J. Plant Sci. 80:669-675.

Chong, C. and P. Purvis. 2004. Nursery crop response to substrates amended with raw paper mill sludge, composted paper mill sludge and composted municipal waste. Can. J. Plant Sci. 84:1127-1134.

Chong, C. and D.L. Rinker. 1991. Spent mushroom compost re-utilized in ornamental crop culture. Mushroom World 2(2):51-52.

Chong, C. and D.L. Rinker. 1994. Use of spent mushroom substrate for growing containerized woody ornamentals: An overview. Compost Sci. Utilization $2(3): 45-53$.

Chong C., D.L. Rinker, and R.A. Cline. $1991 \mathrm{~d}$. A comparison of five spent mushroom composts for container culture of ornamental shrubs. Mushroom Sci. 13(Part 2):637-644.

Chong, C. and M. Wickware. 1989. Mushroom compost trial at Canavonda Nursery. Hort. Rev. 7(6):10-11, 13.

Clear Lake. 1993. Proceedings: Pulpmill waste utilization in the forest. Clear Lake, Edmonton, Alta., Canada.

Dallon, J. 1987. Effects of spent mushroom compost on the production of greenhousegrown crops. Proc. Intl. Plant Prop. Soc. 37:323-329.

Davidson, H., R. Mecklenburg, and C. Peterson. 2000. Nursery management, administration and culture. 4th ed. Prentice-Hall, Upper Saddle River, N.J.

Dolar, S.G., J.R. Boyle, and D.R. Keeney. 1972. Paper mill sludge disposal on soils:
Effects on the yield and mineral nutrition of oats. J. Environ. Quality 1:405-409.

Eames, A.G. 1977. Could spent mushroom compost be used for container shrubs? Mushroom J. 52:114. (Abstr.)

Garner, H.V. 1962. Experiments with farmyard manure, sewage sludges, and two refuses on microplots at schools, 1940-49. Emp. J. Expt. Agr. 30(120):295-314.

Henny, B.K. 1979. Production of six foliage crops in spent mushroom compost in potting mixes. Proc. Florida Sta. Hort. Soc. 92:330-332.

Hermann, D.J. 1982. Considerations for using wastewater sludge as an agricultural and silvicultural soil amendments, p. 79-94. In: C.A. Rock and J.A. Alexander (eds.). Long range disposal alternatives for pulp and paper sludges. Univ. of Maine, Orono.

Hoitink, H.A.J. 2000. Trends in treatment and utilization of solid wastes through composting in the United States, p. 1-13. In: P.R. Warman and B.R. Tayloer (eds.). Proc. Intl. Composting Symp. (ICS 1999). vol. 2. CBA Press, Truro, N.S., Canada.

Jarecki, M.J., C. Chong, and R.P. Voroney. 2005. Evaluation of compost leachates for plant growth in hydroponic culture. J. Plant Nutr. 28:651-667.

Kaddous, F.G.A. and A.S. Morgans. 1986. Spent mushroom compost and deep litter fowl manure as a soil ameliorant for vegetables, p. 138-147. In: Surface soil management. Proc. N.Z. Soci. Soil Sci. and Austral. Soc. Soil Sci., Joint Conf., Roturua, New Zealand, Nov. 1986.

Kraus, H.T. and S.L. Warren. 2000. Performance of turkey litter compost as a slow-release fertilizer in containerized plant production. HortScience 35:19-21.

Ku, C.S.M., J.C. Bouwkamp, and F.R. Gouin. 1998. Effects of compost source and timing of fertigation initiation on growth of potted poinsettia. Compost Sci. Utilization 6:57-66.

Lemaire, F., A. Dartigues, and L.M. Riviere. 1985. Properties of substrate made with spent mushroom compost. Acta Hort. 172:13-29.

Logan, T.J., B.L. Lindsay, and S. Titko. 1997. Characteristics and standards for processed biosolids in the manufacture and marketing of horticultural fertilizers and soil blends, p. 63-71. In: J.E. Recheigl and H.C. MacKinnon (eds.). Agricultural uses of by-products and wastes. Amer. Chem. Soc., Washington, D.C.

Maher, M.J. 1991. Spent mushroom compost (SMC) as a nutrient source in peat-based potting substrates. Mushroom Sci. 12(Part 1):645-650.
Maynard, A.A. 1995. Increasing tomato yields with MSW compost. Biocycle 36(4):104-106.

Maynard, A.A. 1998. Utilization of MSW compost in nursery stock production. Compost Sci. Utilization 6:38-44.

Maynard, B.K. 2002. Evaluating the role of $\mathrm{pH}$ in the rooting of cuttings. Comb. Proc. Intl. Plant Prop. Soc. 50:268-273.

Michitsch, R., C. Chong, R.P. Voroney, B. Holbein, and H.-W. Liu. 2003. Use of spent mushroom compost leachate for growing turf and nursery species in hydroponic culture. Mushroom World $14(3): 21-23$.

National Council of the Paper Industry for Air and Stream Improvement (NCASI). 1959. Pulp and paper mill waste disposal by irrigation and land application. Tech. Bull. 124. NCASI, New York. 36pp.

Ontario Ministry of Agriculture and Food (OMAF). 2003. Nursrey and landscape plant production and IPM. Publ. 383. Queen's Printer for Ontario, Toronto, ON.

Oshins, C. 1995. Strategies for encouraging the use of organic wastes in agriculture, p. 73-86. In: Agriculture utilization of urban and industrial by-products. Amer. Soc. Agron., Madison, Wis. Spec. Publ. No.58.

Pridham, N.F. and R.A. Cline. 1988. Sludge disposal: Completing the ecological cycle. Pulp and Paper Canada 89(2):173-175.

Raymond, D.A., C. Chong, and R.P. Voroney. 1997. Characteristics of composts derived from waxed corrugated cardboard. Compost Sci. Util. 5:60-70.

Raymond, D.A., C. Chong, and R.P. Voroney. 1998. Response of four container grown woody ornamentals to immature composted media derived from waxed corrugated cardboard. Compost Sci. Util. $6: 67-74$.

Reeleder, R. and B. Capell. 2001. Efficacy of composted turkey manure and quintozene for control of damping-off in ginseng, 1996-1998. In: Biolog. and Cult. Tests for Control of Plant Dis. 2001:V89.

Rosen, C.J., T.R. Halbach, and B.T. Swanson. 1993. Horticultural uses of municipal solid waste composts. HortTechnology 3:167-173.

Rowat, C.A. 2000. Production of Jack pine (Pinus banksiana) bark compost for use as nursery container media. M.Sc. Thesis, Dept. Land Resource Sci., Univ. Guelph.

Shiralipour, A., D.B. McConnel, and W.H. Smith. 1992. Uses and benefits of MSW compost: A review and an assessment. Biomass and Bioenergy 3:267-279. 
Shiralipour, A., D.B. McConnel, and W.H. Smith. 1994. Applying composts to crops. Biocycle 34(6):70-72.

Skimina, C.A. 1980. Salt tolerance of ornamentals. Comb. Proc. Intl. Plant Prop. Soc. 30:113-118.

Smith, E.M. 1982. Mushroom compostIs it safe to use as a mulch or potting soil? Ohio Nursery Notes 15:2.

Thacker, W.E. 1986. Silvicultural land application of wastewater and sludge from the pulp and paper industry, p. 41-54. In: D.W. Cole (ed.). The forest alternative for treatment and utilization of municipal and industrial wastes. Univ. of Washington Press, Seattle.

Tripepi, R.R., M.W. George, A.G. Campbell, and B. Shafii. 1996. Evaluating pulp and paper sludge is a substitute for peat moss in container media. J. Environ. Hort. 14:91-96.

Tyler, H.H., S.T. Warren, T.E. Bilderback, and K.B. Perry. 1993. Composted turkey litter. II. Effect on plant growth. J. Environ. Hort. 11:137-141.

Wang, H.S., V.I. Lohr, and D.L. Coffey. 1984. Spent mushroom compost as a soil amendment for vegetables. J. Amer. Soc. Hort. Sci. 109:698-702.

Warman, P.R. and B.R.Taylor (eds.). 2000. Proc. Intl. Compost Symp. (ICS 1999), vol. I and 2. CBA Press, Truro, N.S., Canada.

Wuest, P.J., H.K. Fahy, and J. Fahy. 1995a. Use of spent mushroom substrate (SMS) for corn (maize) production and its effect on surface water quality. Compost Sci. Utilization 3:46-50.

Wuest, P.J., D. Levanon, and Y. Hodar (eds.). 1995b. Environmental, agricultural and industrial uses of spent mushroom substrate from mushroom farms. Proc. from Spent Mushroom Substrate Symp., 11-14 Mar. 1994, Philadelphia. J.G. Press, Emmaus, Pa.

Young, J.R., E.J. Holcomb, and C.W. Heuser. 2002. Greenhouse growth of marigolds in three leached sources of spent mushroom substrate over a 3-year period. HortTechnology 12:701-705. 